\title{
Self-annihilation, nuclear play and West Germany's compulsion to repeat
}

\begin{abstract}
This article investigates Fallex 66, the first of a string of NATO war games that the West German government played in its command bunker between 1966 and 1989. During this exercise, the Bonn Republic simulated nuclear strikes on its 'own' targets and the resupply of NATO forces after a nuclear war on German territory. Whilst in line with West German deterrence at the time, Fallex was read in East Berlin as an excessive game of playful self-annihilation in ways that invite a psychoanalytic interpretation. This article explores Fallex 66 not simply as an enactment of Cold War deterrence, but a Freudian 'fort-da' game, a traumatic re-enactment that was tellingly set in the subterranean space of a German bunker. West Germany's compulsion to self-abandon, I suggest, has important implications for how we understand the nature of geopolitical games.
\end{abstract}

'The darkest aspects of the final act of destruction, as experienced by the great majority of the German population, remained under a kind of taboo like a shameful family secret, a secret that perhaps could not even be privately acknowledged' (W.G. Sebald, 1999, On the Natural History of Destruction, p. 10)

Keywords: Germany, ludic geopolitics, archival research, psychoanalysis, Cold War, bunkers

\section{Introduction}

October 1966. Supermarkets and petrol stations are emptied. Migrant workers try to escape West Germany along its motorways as armed insurgencies spread across the young republic. Communist agitators take over the streets, turning peace protestors into rioters, sex workers into spies and foreign grocers into bioterrorists. In Marienthal, not far from the capital of Bonn, black Mercedes-Benz limousines and army busses pull up in front of a disused railway tunnel. They are chauffeuring the republic's political elites to a safe haven. Behind 25-ton blast doors and more than 100 meters underground lies the West German governmental nuclear bunker, a concrete survival pod for the thermonuclear age. The chosen few are greeted by bunk beds, canteen food, stuffy air and neon light. Hunched over strategic maps, they are subjected to an influx of 
information on political developments and enemy troop movements. As Warsaw Pact forces cross the inner German border, the war begins. It ends only after the North Atlantic Treaty Organisation (NATO) has made use of its first use policy to create a cordon of radioactive rubble on West German territory.

Luckily, Fallex 66 (NATO speak for 'fall exercise') was 'just' a game, a hybrid of civil defence exercise and war game that aimed to determine whether NATO members would be able to act smoothly in the early stages of World War III. And yet, the exercise left a bitter aftertaste. Not only had the West German republic's elites called on NATO to deploy nuclear weapons early on in the game, but they had also requested for these to be launched onto West German territory. Somewhat puzzlingly, the West German state therefore simulated geo- and biopolitical self-annihilation. This article tries to make sense of this subterranean self-abandonment, ritually repeated in the controlled environment of the nuclear bunker until 1989. It is based on archival research at the Federal Archives in Koblenz, its Military Department in Freiburg as well as the Federal Commissioner for the Stasi Archives in Berlin and the National Archives at Kew. ${ }^{1}$

Taking my cue from the emerging geographical debates around ludic geopolitics (or playful geopolitics), I make a case for the fundamentally unplayful nature of war games like Fallex 66. After subjecting the existing literature on geopolitical games to a critical reading, I unpack the exercise's script, gameplay and context within West German geopolitics of the 1960s. Subsequently, I zoom in on the East German reception of Fallex 66, which read the war game as a forbidden and obscene enjoyment of selfannihilation. Drawing on psychoanalysis, I argue that the game compulsively repeated the fundamental trauma that gave birth to the West German state - the German defeat in World War II and the destruction of German cities by Allied bombing campaigns. In the West German context, Fallex 66 functioned as a 'fort-da' game, a term Sigmund Freud (1920[2001]) used to classify his grandson Ernst's compulsive habit of abandoning toys only to move them back into view. As in the case of the infant who staged his own disappearance and return in order to compensate himself for his loss, the West German state playfully participated in the annihilation of its own cities on paper. In this way, the Federal Republic sought to master rather than mourn the experience of urbicide and the subsequent restriction of West German sovereignty by replicating the traumatic experience, but this time assuming the position of the abandoner.

\section{Ludic geopolitics and beyond}

Whilst the language of games has long permeated both the conduct of and writing about war and diplomacy (Salter 2011a), the politics of play has only started to receive attention from geographers relatively recently (Adey \& Anderson 2012; Carter, Kirby \& Woodyer 2015; Ciută, 2015; Dittmer 2013; MacDonald 2008; Power 2007; Shaw 2013; Shaw \& Sharp 2013; Woodyer 2012; Yarwood 2015). In this turn to play, games are increasingly recognised as constitutive of geopolitics itself, the violent mapping and writing of the earth. Seen to extend from the nursery all the way to the war room, scholars have explored ludic geopolitics in geopolitically themed computer games, civil defence simulations, strategy board games, risk management exercises and war toys. This literature has investigated how games fictionalise and make intelligible a complex reality

\footnotetext{
${ }^{1}$ All translations from German into English are the author's. The East and West German newspaper articles cited below had been carefully compiled by the East German secret service and were thus conveniently available for the author's review in the Federal Commissioner for the Stasi Archives.
} 
but also how they fuse representational, corporeal and affective dynamics to produce geopolitical order. Perhaps most importantly, play has been investigated in its experimental and potentially disruptive capacities.

The earliest and now sometimes forgotten way in which games entered the study of geopolitics was through a concern with game theory. Whilst war games had always united military strategy and mathematics in an enthrallment with the medium of the game (von Hilgers 2012, x), Cold War strategic thinking mastered the art of condensing such war games into mathematical matrices. Schooled in a blend of political realism, geographical determinism and game theory (Dalby 1990, 175), Cold War strategists read the conflict with the USSR through 'games' like the 'prisoner's dilemma' or the 'game of chicken', in which two opponents are headed for a fatal collision but unwilling to be the first to retreat. Following the logic of this game, the players would deliberately communicate irrational behaviour that did not necessarily reflect actual war plans to scare the opponent into giving up. ${ }^{2}$

Since the early 2000 and the onset of the war on terror, academic debates have increasingly returned to games in an attempt to address the spread of military technology into the most capillary social relations (Lenoir 2000; Der Derian 2001). Such games are increasingly seen to disperse orientalist imaginative geographies amongst gamers (Graham 2006) and rewire the relationship between entertainment, propaganda and army recruitment (Stahl 2010). ${ }^{3}$ Simultaneously, Geographers started to make arguments about the theatricality and creativity of play. Geopolitics, they implied, is rehearsed, staged and performed, though in ways that often produce unpredicted effects. According to this reading, Cold War militarism was enacted in the most mundane settings though play (MacDonald 2008, 612) and civil defence drew 'directly upon the traditions and techniques of the stage' (Davis 2007, 2). Thus, contemporary simulations, too, are read as materially contingent 'enactments' (Adey \& Anderson 2012, 114) that emerge from an affective interplay of performer and audience (Dittmer 2013, 7).

In doing so, Geographers have increasingly pointed towards the ambiguous and experimental nature of these playful performances. Though cautioning against overly emancipatory readings of games, Hughes $(2010,126)$ has argued that play is neither predetermined nor determining. Similarly, Power emphasises that 'games are often used in ways not intended or anticipated by their developers or military sponsors' and that 'data, rules and codes can be modified to produce different narratives' (Power 2007, 282). Adey and Anderson have called on scholars to take seriously the 'creative and surprising or unpredictable and contingent' elements of 'exercise play' (Adey \& Anderson 2012, 103; see also Shaw 2013, 793). Some authors have even understood play as a realm of 'fundamental creativity' that holds 'political possibilities' (Shaw \& Sharp 2013, 342, 344). This reading draws attention to the disruptive possibilities of play, its ability to obstruct the smooth exercise of power, to question authority and spark political transformation.

In what follows, I suggest a psychoanalytically informed alternative to the emerging debates on ludic geopolitics. In an attempt to grapple with a very particular geopolitical game - a nuclear war game - I emphasise the traumatic, self-destructive, and non-playful dimension of certain games. Whilst nuclear play exhibits some of the characteristics of games, such as rules, players and decision-making, it crucially lacks its disruptive and transformative properties. Fallex 66 neither unlocked the creative

\footnotetext{
${ }^{2}$ If known to the enemy, war games like Fallex 66 could of course play a part in the practice of deterrence (Geenen 2006, 51).

3 From this perspective, war games might appear as the true models for commercially produced games like Diplomacy, Risk or Civilization (Salter 2011b).
} 
capacities of its players, nor did it replace the normal laws of society in a carnevalesque state of exception. When placed within its political context, it becomes clear that the West German participation in Fallex 66 was more than a mere rehearsal of the Cold War or a performance of deterrence. Instead, it compulsively re-enacted the German experience of urbicide and the loss of sovereignty in the space of the bunker. Whilst players would have been aware that Fallex 66 was 'just a game', at a deeper level, they were acting out something that was perhaps a little 'too real' to acknowledge.

\section{Fallex 66 and West Germany's nuclear play}

Having disappeared from Europe's map as a great power, Germany, or rather what was left of it, was swiftly divided by the Allies after 1945. Given the scale of both the defeat and the German war crimes, the Third Reich's two successor states had to tread carefully in the international arena. Soon it became clear on either side of the iron curtain that Germany would be likely to serve as the battlefield for the next world war.

Founded in 1949, the Federal Republic of Germany (FRG) swiftly moved to embrace the North Atlantic alliance's nuclear deterrence in the hope that it might thereby secure the country's independence from Soviet influence (Thoß 2007, 34). Firmly rejecting a policy of neutrality, West Germany's first chancellor Konrad Adenauer (1949 and 1963) had warned at an early stage that 'Asia was on the river Elbe' (Adenauer, 1946). The devoted Americanophile and anti-Communist would later become known for his 'policy of strength' vis-à-vis Moscow (Politik der Stärke) and an unequivocal 'Western orientation' (Westbindung), which came to define German defence policy. Given this ideological compatibility with Washington's Cold War discourse, Adenauer's Federal Republic's was permitted to join the North Atlantic Treaty Organisation in 1955 despite reservations in many NATO members about Germany's re-militarisation.

Whilst the young semi-sovereign West German state had been keen to develop its own nuclear weapons programme, it had been forced to renounce any ambitions of acquiring its own atomic, biological or chemical weapons at an early stage. Too controversial was the idea that Bonn would accomplish what the Third Reich had tried in vein - to acquire the bomb. And yet, the North Atlantic Council soon worked out a compromise, the so-called nuclear sharing initiative, which allowed non-nuclear powers like Germany, Turkey, Belgium, the Netherlands and Italy to participate in nuclear planning, stationing and delivery of nuclear weapons. As a consequence, the West Germans could at least simulate some form of nuclear status.

In a sense, however, this policy only allowed Bonn participation in what had already begun on the ground, namely the nuclearisation of West German territory by the United States. Starting in the early 1950 os, this process had met little resistance from the leadership in Bonn. In 1953, the West German weekly TV programme Welt im Bild enthusiastically celebrated the arrival of the first six M65 atomic cannons. Capable of delivering nuclear warheads with a yield that approached that of the Hiroshima bomb, 'Atomic Annie' was praised for its 'wonderful adaptability to the local context' (Die Neue Wochenschau, 1953). Only in passing, the programme mentioned that the nuclear cannon had a reach of no more than 22 miles. The local context in which it was to be used was of course Germany itself.

In order to build a consensus for West Germany's nuclearisation, these new weapons had to be euphemised. And so, in 1957, Chancellor Adenauer would declare that tactical nuclear weapons were 'nothing but the further development of the artillery' (Der Spiegel, 1957). Given the low range nature of the tactical weapons stationed in West 
Germany and the fact that they were meant as 'defensive' capabilities that were to be used only after an invasion of the Soviet Union, it was clear that the nuclear weapons stationed in Germany were designed for use on German territory.

As historians started to point out by the late 1980s, West Germany's frontline soldiers were assigned 'the task of staving off a Soviet assault long enough for NATO to drop nuclear warheads above them', rendering them the 'atomic cannon fodder of a future war' (Cioc, 1988: 9). By 1965, the alliance had placed 500-550 such nuclear land mines on the West German side of the iron curtain and a further 200-240 nuclear weapons further inland. As it has recently emerged, it was the Federal Republic rather than the United States that actively sought to install this cordon of so-called 'atomic demolition munition' (Bald 2008, 52). It is in this context that we need to situate Fallex 66.

Fallex 66 was an 18-day NATO-wide exercise, involving NATO member states, the North Atlantic Council and the Major NATO commanders. Played in October 1966, it was the first and publicly most visible of twelve NATO exercises in the Fallex/WintexCimex series, the last of which took place in $1989 .{ }^{4}$ These events simulated the transfer of NATO into a state of war, the testing of the alliance's alert systems and the practicing of decision-making in real time. In this sense, Fallex 66 presented an opportunity for the West German government to 'influence the actions of NATO forces under the pressure of fast decision-making', as the East German secret service concluded (Ministerium für Staatssicherheit 1966a). The UK Ministry of Defence Chiefs of Staff Committee concluded that Fallex 66 demonstrated 'valuable lessons particularly in nuclear play' (UK Ministry of Defence 1967, A-7).

Rather than involving actual troop exercises, Fallex simulated the interplay of the political elites and the military command in the release of nuclear weapons. Played across the alliance in conjunction with the NATO headquarters, it was therefore a hybrid of a war game and a civil defence exercise. The geopolitical background scenario started with a period of superpower tension during which intelligence procedures and alert measures were practiced and was followed by aggression less than general war and finally an escalation into general war. Whilst the basic narrative was written by NATO, individual allies would add domestic political events to make the storyline more compelling and challenging for the players. West Germany chose to play Fallex 66 under the most realistic conditions possible - in its governmental nuclear bunker near Bonn. Built on the site of a WWII underground concentration camp (Jungbluth 200o), this subterranean citadel had been meticulously prepared in the run up to Fallex 66 to host $\mathbf{1 , 2 0 0}$ selected bureaucratic and military staff. This group included not just representatives of the government, the three branches of the Bundeswehr (armed forces), key ministries and federal states, but also the Federal President and the Chancellor (both of which were played by high ranking bureaucrats).

Fallex 66 was split up into three continuous parts, 'Top Gear', 'Jolly Roger' and 'Full Moon', only the first of which was publicly acknowledged at the time. During the first part, politicians had not only to respond to a number of domestic political crises mentioned in the introduction to this article, but also decide whether to lobby Washington for the use of nuclear weapons. In their nuclear refuge, Defence Minister von Hassel managed to convince the emergency parliament that the use of 'defensive' nuclear weapons, such as the MIM-14 Nike-Hercules, would act to de-escalate the conflict if used on own territory, as a former participant has recollected (Dorn 2002, 107).

\footnotetext{
4 Not all of these have been declassified in the Federal Archives, but extensive intelligence on the later ones is available in the Federal Commissioner for the Stasi Archives in Berlin.
} 
Whilst guidelines on psychological warfare handed out during the exercise were clear that West German politicians would not publicly admit to the use of such weapons (III. Korps Chef des Stabes 1966), they did tacitly acknowledge their self-destructive logic. In a speech prepared for the nation's darkest hour, the President apologetically explained to his citizens that West Germany's defences included weapons that did 'not entirely lie in the hands of the Bundeswehr' (III. Korps Fernschreibestelle 1966). The first part of the exercise ended rather abruptly with a Soviet retreat in the face of NATO's nuclear threat.

After the politicians had left the bunker, the military stayed on for part two, which simulated full-blown nuclear war and during which NATO detonated atomic bombs both on the territory of the East block and on West German territory that had been taken by the advancing Warsaw Pact armies. The Bundeswehr had already played a crucial role in bringing out the self-destructive tendencies in the first part of the game by requesting the right to forcefully remove refugees from key transport routes (III. Korps Leitungsstab 1966). Only hours after the invasion had begun, it called for nuclear weapons to be released and bemoaned an 'inexplicable timidity' on the side of NATO to set off its nuclear landmines (III. Korps Leitung 1966). When the battle finally arrived, the military furthermore requested Napalm to be used against the Warsaw Pact forces, again on West German territory (ibid). All of this was at a time when West German cities had only been partially evacuated - around 300,000 refugees were still wandering through the most intense fighting zone. The second part of Fallex 66 ended only after NATO had created a $50 \mathrm{~km}$ impenetrable cordon of radioactive destruction, from Göttingen in the North to Eslarn on the Czech border (Ministerium für Staatssicherheit 1966a). During the final part of the exercise, the military simulated the post-apocalyptic regrouping and resupply of NATO's remaining forces -29 days after a first exchange of nuclear weapons. In the course of the entire Fallex exercise a total of 340 nuclear strikes from both sides occurred on the Northern territory of the Federal Republic alone (Northern Army Group 1966, C/2/4).

Fallex 66 was variously described in official sources as an 'exercise', 'play', 'nuclear play' or a 'game' with 'players' (Ministerium für Staatssicherheit, 1966b; Northern Army Group 1966, 2-5; UK Ministry of Defence 1967, A-7) and the leader of the West German emergency parliament even called it a 'crap game' (Der Spiegel 1966a, 30). And yet, Fallex 66 actually only allowed for very limited ludic elements, such as a restricted duration and spatial setting, rules, goals and real time decision-making. Its gameplay, however, was so linear that it disallowed any ludic complexity or transformative potential. If the players for instance decided against a particular (hardline) choice, as happened when they initially refused to let the military remove civilians from the motorways with force, they were subsequently bombarded with messages that outlined an ever worsening situation until they finally gave in. Most importantly, the game did not allow for negotiations with the Soviet Union (codename 'Orange'). It was therefore clear for all participants that the only goal was the smooth release of nuclear weapons rather than the prevention of war.

\section{A war game and its reception}


The German public has known about Fallex 66 since 1966, when details of the exercise were leaked to the press (Der Spiegel 1966a 1966b; Die Zeit 1966a 1966b). ${ }^{5}$ Interestingly, both these earlier reports and the more recent attention from German bunkerologists ${ }^{6}$ (Diester 2009, 179; Diester \& Karle 2013, 160; 226; see also Mastny \& Byrne 2006, 242) have focused less on the war game's self-destructive logic than on the way in which it enacted the contentious German emergency laws before they had been passed in Parliament. Encouraged by NATO itself (Northern Army Group 1966, A/11) and finally adopted in 1968, these laws would transfer powers from the legislative to the executive in an emergency through a simultaneously legal and extra-legal 'state of exception' (Agamben 2005). Whilst this politically problematic performance generated unrest amongst West German students, it did not prompt a serious debate as to why the West German state was playfully abandoning its territory and population in its bunker.

Perhaps unsurprisingly, West Germany's nuclearisation had not gone unnoticed on the other side of the iron curtain. By the mid-196os, there were a whole range of nuclear weapons systems on West German territory, prompting the East German secret service to speculate that West Germany was now 'more modern and more generously equipped' than NATO's nuclear capabilities in any other part of the world outside the United States (Ministerium für Nationale Verteidigung, 1964: 16). Understandably, East Germany had produced extensive intelligence on Fallex 66 from an early stage, which had been presented to the GDR leadership, including Erich Honecker and Walter Ulbricht (Ministerium für Staatssicherheit 1966a).

In such reports and related newspaper articles the exercise was predictably read through the lens of Marxist-Leninist doctrine, particularly as evidence of Western imperialists' and monopoly capitalists' aggressive plans for world domination (Ministerium für Staatssicherheit 1966b 1966c, 17). Interestingly, however, there was also a noticeable undertone of enjoyment, even of a sexual kind, in these reports of nuclear self-harm that is uncommon in Cold War discourse. ${ }^{7}$ In this way, the Stasi accused the West German political elite and especially the West German Social Democrat Party (SPD) of using Fallex 66 to channel its 'lust for dictatorship' (Ministerium für Staatssicherheit 1966d). Likewise, the official party organ Neues Deutschland (1966b) reported that the leadership was participating 'lustfully' in the American nuclear war game and in the liberation of the East. Under the 'passionate' participation of the 'degenerate' social democrats, West German generals were finally able 'to fulfil their dream' of 'pushing the button and starting a nuclear war' (ibid).

The element of enjoyment became particularly visible in stories of excessive consumption and sexual harassment in the bunker. Whilst these stories may have originated in West German press reports on alcohol consumption, banquets and nocturnal parties during Fallex 66 (Der Spiegel 1966a, 30 1966b, 27), East Berlin inflated them. An East German propaganda flyer, possibly produced for circulation in West Germany claimed that the bunker's corridors and sanitation had been heavily contaminated from excessive drinking and that women had been sexually harassed during the exercise (no author 1966). A few months later, a spy report on the bunker, added a subterranean casino to the story that had, or so it claimed, been designed to entertain the bunker's inhabitants whilst deprived from the joys of capitalism

\footnotetext{
5 Fallex 62, a 1962 exercise, had famously led to a scandal after the magazine Der Spiegel had revealed the country's lack of preparation for war (Der Spiegel 1962). The state subsequently attempted to shut down the magazine, but backed down in the face of mass demonstrations.

${ }^{6}$ For a discussion of the practice of bunkerology see Bennett (2011a).

7 Note that whilst Ó Tuathail and Agnew $(1992,200)$ have pointed out the sexual undertones of early Cold War American geopolitical discourse, their work did not did not include the dimension of self-harm.
} 
(Ministerium für Staatssicherheit 1967, 5o). In effect, the bunker was turned into a space of subterranean luxury, excessive sexuality and forbidden political enjoyment. ${ }^{8}$ These stories culminated in a 1967 East German newspaper article that speculated about wild orgies during Fallex 66. 'Against the free flow of sparkling wine and other alcohol', it explained, 'brawls and excessive indecencies occurred' (Tribüne 1967).

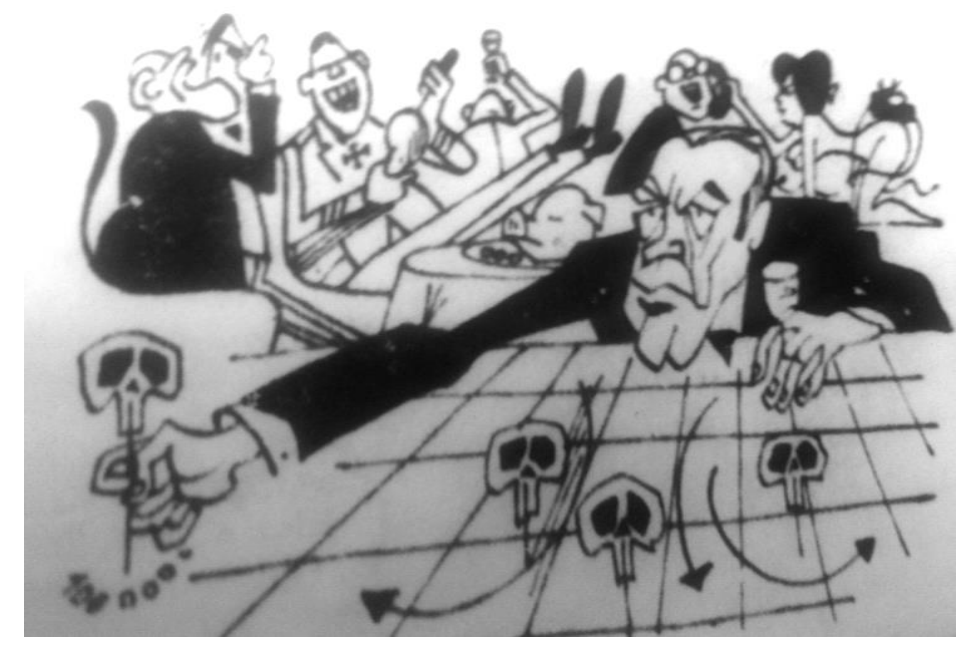

Images 1 Cartoon from the East German press (Tribüne 1967).

These graphic scenes were visualised in a cartoon that is symptomatic of this East German fascination with Fallex 66. It shows a grim looking West German politician ${ }^{9}$ leaning above a blend of a casino board (note the black tie) and a strategic map (showing a geographic coordinate system and arrows). He is seen pinning down stylised mushroom clouds whilst a full-blown orgy is on its way in the background. Seemingly unbothered by the megadeaths, men are enjoying alcohol, pork (a reference to the greediness of capitalism) and telephone calls (a symbol of wealth in 196os East Germany) as well as the company of a lightly dressed woman in a subservient pose. A military officer has joined the party, wearing a Wehrmacht uniform.

Indeed, both in official documents and in newspapers, the exercise was frequently equated with Hitler's final battle and the West German nuclear refuge was compared to Hitler's Wolf's Lair bunker (Ministerium für Staatssicherheit 1966c, 30; Berliner Zeitung 1966; Neues Deutschland 1966a). Clearly, East Berlin was shocked by the way in which West Germany was willing to simulate self-harm and likened this 'terror against the population' to the Third Reich's drive towards self-annihilation (Ministerium für Staatssicherheit 1966d). And yet, it is also clear that East Berlin saw in Fallex 66 an enjoyment of Nazi geopolitics and biopolitical annihilation. ${ }^{10}$ The East German interpretation thus hinted unmistakably at something traumatic at the heart of Fallex 66, something that had not just to do with the war game itself but with something much larger." Maybe the East Germans, however ideologically blinkered they may have

\footnotetext{
${ }^{8}$ During a similar exercise in 1975, the East German press construed a knife attack on a female secretary not as attempted murder but as a sexual assault (Berliner Zeitung, 1975).

9 This was probably the Christian Democrat Minister of the Interior at the time, Paul Lücke.

${ }^{10}$ Gregory (2011: 261) notes that whilst the term annihilation is today usually reserved for the holocaust, it was also frequently used in British and North American discussions of the Allied bombing campaigns during the 1940 and therefore has a wider function within discourses of total war.

${ }^{11}$ The controversies that emerged around Fallex 66 and similar exercises in West Germany would suggest that West Germans too were somewhat uneasy with these simulations, but they did not go so far as to insinuate a subterranean enjoyment in self-harm.
} 
been, saw something that the West Germans were perhaps at the time unable - or indeed unwilling - to see.

It is precisely this reading of Fallex 66 as a simultaneously pleasurable and nonpleasurable game of self-annihilation that, I argue, invites a psychoanalytic interpretation. For this form of painful pleasure that is 'alluring yet threatening' is of course at the heart what Lacanian psychoanalysis calls jouissance or enjoyment (Kingsbury 2008, 50). In this sense, the concept of enjoyment captures that which is pleasurable (sexually or otherwise) and that which is beyond the pleasure principle but which the subject nevertheless strives towards. Enjoyment thus captures something excessive, transgressive and traumatic, something that has the power to convert things into their opposite, the ability 'to render inexplicably attractive what is usually considered a loathsome act' (Žižek 1991 13). ${ }^{12}$

\section{Fort. Da.}

Whilst psychoanalytic approaches are far from new to human geography (Pile 1996; Social \& Cultural Geography 2003), attempts to think political geography and geopolitics through notions of desire, lack, fantasy or libido are mostly rather recent (Müller 2013; Nast 2003; Shaw, Powell \& De La Ossa 2014). Like in other academic fields, psychoanalytic geographies seek to unearth agencies that escape consciousness by interpreting narratives, symptoms as well as socio-material settings. Psychoanalytic theory is particularly useful for an analysis of seemingly 'irrational' behaviour and has long developed the conceptual tools to dissect the dynamics of repulsion and desire that surround phenomena like nuclear weapons or the euphemistic and self-deceptive discourses of nuclear deterrence. In this way, the paper builds on Kingsbury's insistence that psychoanalysis offers geographers 'methodological inquiries into the ways in which desire and drive inform socio-spatial relations' (Kingsbury, 2010: 530).

In 1995, the late British psychoanalyst Hanna Segal noted in a piece on nuclear war that whenever psychoanalysts tried to apply their insights to areas outside the clinic, there was usually 'an outcry that this [was] not the province of psychoanalysis' (Segal, 1995: 191). And yet, she insisted not just that Freud had always been interested in the relationship between individuals and society, but also that psychoanalysis was particularly apt in approaching the phenomenon of nuclear warfare. After all, nuclear planning and strategy displayed the very self-destructive and irrational behaviour that psychoanalysts had long sought to examine (see also Jacobsen 2013, 17). She argued in particular that the bomb aroused the most primitive psychotic anxieties about annihilation, and mobilize[d] the most primitive defences' (Segal, 1995: 197-8) and that nuclear strategy was 'like a surrealist scenario, an unbearable nightmare or a psychosis' (Segal, 1997: 117). Given that the interpretation of collective fantasies or nightmares in films and novels is now well established throughout the humanities, there is arguably no reason why the state-sponsored fantasy of nuclear war should be spared the same treatment.

\footnotetext{
${ }^{12}$ It is interesting to point out that in 1966, the GDR had started planning a new governmental nuclear bunker of its own that roughly resembled its West German counterpart in design and function (Diester \& Karle, 2013). It also included similar, though less elaborate simulations that played through nuclear war (Freitag \& Hensel 2010, 153). Despite its seeming repulsion by the events in West Germany's governmental bunker, it was therefore engaging in very similar games. We are instantly reminded of Freud's notion of emotional ambivalence, the idea that within love is hostility in the unconscious and vice versa (Freud 1913[2001], 70; see also Beck 2011, 83).
} 
Indeed, we may add to this that Freud himself was directly concerned with the question of self-destruction, not merely of an individual but a society, even a species. In Civilization and its Discontents, he warned that humans had 'gained control over the forces of nature to such an extent that with their help they would have no difficulty in exterminating one another to the last man' (S. Freud 1989[1930], 112), a statement often taken to anticipate the holocaust, it also uncannily foreshadows the technological possibility of nuclear extermination. In this paper, I turn to the Freudian concepts of the 'compulsion to repeat' to make sense of Fallex 66. The point in following Freud into his conception of the death drive is not so much to ontologise aggression or to oppose 'aggression' to 'civilisation', as he did in Civilisation and its Discontents, but to propose that human subjects repeat non-pleasurable behaviour and that these self-destructive rituals can often be linked back to traumatic experiences of physical and symbolic violence.

Whereas Freud had been convinced that that the psyche was governed by the so-called pleasure principle for most of his career, he started to question this earlier conviction in the later stages of his oeuvre as he grappled with forms of destructiveness, which seemed to elide the pursuit of pleasure and the avoidance of pain. Freud was particularly puzzled by non-pleasurable and repetitive behaviour that he referred to as 'the mysterious masochistic trends of the ego' and that he had observed not just in children's play, but also in the behaviour of soldiers who had returned from the trenches of WWI (Freud 1920[2001], 14). He concluded that these neurotic effects were best understood as a return of the repressed, a compulsion to repeat that stemmed from earlier traumata that were playing out in the present.

Freud used these observations to propose his theory of the death drive, positing that next to other (such as sexual) drives, humans were subject to a self-destructive drive for which life was all but a short inconvenience. Freud saw the drives as subject to a different and more complex economy of desire. Unlike instincts (such as hunger or thirst), which are simply directed at satisfaction, Freud's drives encircle objects, thus resulting in 'excessive, repetitive and potentially destructive' patterns (Kingsbury, 2010: 520). The paradox of non-pleasurable behaviour is thus resolved by an understanding of how actions that are non-pleasurable to the conscious subject can be pleasurable for its drives, located at the level of the unconscious. In short, the subject keeps putting itself in unpleasant and disturbing situations because it is here that the drive can encircle its object.

Freud famously illustrated his concept of the death drive in his 1920 essay Beyond the Pleasure Principle through the 'fort-da' game, a compulsive game that he had observed in his grandson Ernst. The 18 months year old boy, who had lived in the same house as Freud for a while, had displayed the irritating habit of abandoning toys only to move them back into view. The child repetitively performed this game on a number of objects, including a wooden reel attached to a string, which enabled him to effortlessly ritualise the exercise. He would typically exclaim 'o' when discarding an object (which Freud interpreted as standing for the German word 'fort') and a joyful 'da' ('here') upon embracing it. He would also play a variation of this game by standing in front of a mirror and making himself disappear by moving out of view.

Freud unpacked this little game of disappearance and return by contextualising it within the child's relationship with his parents who had praised the boy as particularly well behaved. 'Above all', Freud remarked, 'he never cried when his mother left him for a few hours' (Freud 1920[2001], 14). Freud held that the departure of the mother, Freud's daughter Sophie, could not have left the child indifferent and that his repetitive game therefore was a return of the repressed (he was not allowed to cry). 'Throwing away an 
object so it was "gone" might satisfy an impulse of a child's, which was suppressed in its actual life', Freud speculated. But whilst he saw the child's urge 'to revenge himself on his mother for going away from him' (16), another reading would emphasise that the child abandoned itself. Ernst had after all played an even more revealing version of the game in which he made himself disappear in front of a mirror.

Seen in this light, Freud's grandson used the mirror to place himself in the position of his mother. He compensated himself for his great achievement of not crying by staging his own disappearance and return, as seen by his abandoner. In this sense then, the fort-da game was an attempt to 'master rather than mourn' a situation of loss over which he had no control, in this case the disappearance of the mother (Kingsbury \& Pile 2014, 4). The game demonstrates both the movement from passivity to activity as well as the constitution of desire through mimesis; the child wishes to abandon its passivity for the mother's active position. All of this happens in play. 'To appear in the place of another' is an act of identification that is always already playful 'in the sense in which one plays a role' (Borch-Jacobsen, 1982, 35). By playing his mother over and over again, Freud's grandson was effectively caught up in the attempt of constituting himself as an independent and active subject.

\section{Self-annihilation}

It is in this idea of a subject that simulates but in effect lacks autonomy that we can suggest some tentative connections to our West German case. This is not to infantilise the young semi-sovereign republic but rather to suggest that like traumatised subjects, states too can show a compulsion to repeat. It is important to stress that West Germany did not have a veto over the use of tactical nuclear weapons on its own territory - but merely the right to consult the United States in its decision to use such weapons (Buteux 1983, 104). After a Soviet invasion, Bonn would have been at the behest of Washington, much in the same way as Germany's urban population had been at the will of the Allied bombing squads in the final days of World War II. There are, I would like to argue, four further clues that point us in the direction of Fallex 66 as a Freudian 'fort-da' game: the self-destructive and repetitive nature of the game, the element of enjoyment as seen by an external observer and the setting of the game within the simultaneously traumatic and tabooed space of the bunker.

Firstly, Fallex 66 was clearly a suicidal game for West Germany, even though it was not acknowledged as such by the majority of West German commentators at the time. By the 1980s, however, nuclear strategists and peace activists were united in pointing out the self-destructive tendencies at the heart of West German geopolitics. As the military analyst Werner Ebeling warned, the FRG would be "the first and "total" aim of conventional and nuclear destruction, the battlefield of a war in Central Europe, with incomparably higher human and material losses than elsewhere' (Ebeling, 1986: 31). Other critics spoke of West Germany's approach to nuclear war as 'suicidal defence' (Afheldt, 1983: 13) or a play with 'national suicide' (Borinski 1989, 531).

Secondly, Fallex 66 was a repetitive game. As mentioned above, it was only the first and publicly most visible of twelve NATO exercises in the Fallex/Cimex/Wintex series that were ritually played in the bunker until 1989. The vast majority operated with surprisingly similar storylines. After geopolitical tensions in the East block and a build up of troops along the inner German border, the war would begin. NATO would respond with the selective release of nuclear weapons, often after the use of chemical weapons 
by the Soviet Union. Most importantly, the majority of exercises simulated the West German request for nuclear weapons. Even during Wintex 85, an exercise that was explicitly designed without the need for atomic weapons, the West German government demanded the use of such weapons, as was widely reported at the time (Der Spiegel 1985; Süddeutsche Zeitung 1985). This caused a public uproar, to which NATO headquarters responded, apologetically yet somewhat ironically, that the game had 'no relationship to political reality' (Volksblatt Berlin, 1985).

Thirdly, East Berlin spotted in Fallex 66 and later games an element of enjoyment. In doing so, it was, much like a psychoanalyst, operating at a partial distance to the game. This meant that it was sufficiently involved to understand the game's deeper historical meaning but external enough to make the crucial observation that the West German state was engaged in something it could only do in the subterranean and forbidden space of the bunker. Whilst East Berlin's reading of the exercise was clearly ideologically tainted and informed by tropes of bourgeois decadence and Western degeneracy, it was also remarkable in its framing of the exercise. By juxtaposing annihilation, over-consumption and sexuality, the East Germans hinted at a distinct combination of pleasure and non-pleasurable enjoyment in rather a similar way to what Freud had observed in his grandson's game. The East Germans could see that the kernel of Fallex 66 was precisely the kind of geo- and biopolitics that had turned on itself during Hitler's twelve year Reich and that the post-war German state had been denied (Bassin 2003, 361).

Finally, like the original 'fort-da' game, Fallex needs to be understood as 'profoundly spatial' exercise (Pile 1996, 134); it is about hierarchical relationships that manifest themselves in space (fort, $d a$ ). It is important to remember here that the West German government chose to play Fallex 66 in a very particular space - the nuclear bunker. Whilst there may have been strategic reasons for Bonn to host Fallex in its command bunker, it is important to note that elsewhere the exercise was played above ground. As NATO noted casually in one of its post-exercise reports, play had been conducted from 'peace locations' and 'during extended working hours' (Northern Army Group 1966, 5). Much has been written on the nuclear bunker's function as both a 'shelter' and 'grave' (Bennett, 2011b 156), a 'womb' and a 'tomb' (Beck 2011, 82). Indeed, nuclear bunkers are not just geopolitical spaces (i.e. places where geopolitics becomes tangible), but they are biopolitical even necropolitical spaces, too. Nuclear command bunkers are not just places where sovereign power seeks shelter from the nuclear holocaust outside, but they are also the political spaces in which the sovereign decision over survival or extinction is located during in nuclear war (author reference). By constructing the present as past in an apocalyptic future, nuclear bunkers always already play with an aesthetics of 'disappearance' (Virilio 1975, 57; Vanderbilt 2002, 128) that resembles the compulsive disappearance of Ernst. They are places in which even selfextermination may become rational under certain circumstances.

In his excavation of London's highly securitised MI6 Headquarters, Pile (2001) argues for an appreciation of the built environment's repressed underside. If we follow this approach, a seemingly forgotten bunker beneath the Federal Republic's nuclear bunker comes into vision that reveals an early history of extermination on this very site. Before the West German government had constructed its nuclear command bunker in Marienthal, the site had served as an underground slave labour camp that had produced the $V_{2}$ rocket. Although the $V_{2}$ is often remembered as a military failure, it did of course serve as the prototype for both the Soviet and North American ballistic missile programmes, and therefore could be seen as a fundamental technological innovation that heralded the Cold War (author reference). The site's reinforced concrete had also, 
in the final months of the war, given shelter to civilians who were fleeing from Allied bombardments that were increasingly targeting surrounding villages (Bundesinnenministerium, 1959). In 1960, this dark history was acknowledged in ministerial correspondence by a man called Theodor Busse (Bundesinnenministerium, 1960). A former Wehrmacht general who had himself been involved in Hitler's selfdestructive battle until the final hour, Busse is likely to have written the West German script for Fallex 66 (Diester, 2009: 181). Here we get a sense of the many links and continuities between the Third Reich's genocidal war, which culminated both in the desire for ever deadlier weapons in Germany and aerial bombing campaigns against Germany, and the early Cold War.

Much has been written about the role of the Holocaust in the re-construction of post-1945 German national identity, but whilst few Germans had seen a camp from the inside, many had personal memories of Allied bombing. The destruction of German cities and towns functioned as a publicly visible implosion of the fascist fantasy and its aim of conquering Eastern lebensraum. It was the moment when the genocidal war fell back on the 'chosen' volk itself, and the bunker, rather than the camp, was for many Germans the spatial setting in which this final episode was experienced. In this sense, the bunker therefore was not just a paradigmatic fascist space because of the Führer's suicide in his Berlin command bunker, but also because of the large scale civilian bunker programmes that had mushroomed in German cities during the early 1940 s in response to the threat of Allied bombardment. The population's retreat into these wombs/tombs, as their cities increasingly turned into ruins, one could argue, was in a sense only the logical consequence of National Socialism's ideological obsession with soil, death and ruins.

Nevertheless, and this is the important twist here, the memory of these traumatic events was tabooed in post-war Germany until the 1990s when a debate on the destruction of German cities started to emerge (Zehfuss 2007, 78). Reading the taboo as an attempt to constrain the simultaneity of conflicting impulses, Freud (1913[2001]) argued that particular compulsive or obsessive acts arose in response to self-imposed prohibitions. The German émigré writer W.G. Sebald was puzzled by precisely such a taboo, by the way in which his countrymen had treated the annihilation of their cities as a 'shameful family secret' (Sebald, 1999: 10). He was struck by the 'extraordinary faculty for self-anaesthesia shown by a community that seemed to have emerged from a war of annihilation without any signs of psychological impairment' (11). He observed that

'The almost entire absence of profound disturbance to the inner life of the nation suggests that the new Federal German society relegated the experiences of its own prehistory to the back of its mind and developed an almost perfectly functioning mechanism of repression, one which allowed it to recognize the fact of its own rise from total degradation while disengaging entirely from its stock of emotions, if not actually chalking up as another item to its credit its success in overcoming all tribulations without showing any sign of weakness' (11-12)

It is precisely this unwillingness to show weakness in the face of traumatic experiences that accompanied West Germany's willing participation in Fallex 66. Whilst West Germany's new Allied guardians actively encouraged the Federal Republic to participate 'as fully as possible' in all stages of nuclear self-destruction (Northern Army Group 1966, C/2), the Germans were eager to show that they were brave enough to do so. At a number of occasions during the game, the Bundeswehr emphasised that neither the 'war of brothers' with East Germany nor the many casualties of nuclear war 
impressed its soldiers enough to destabilise morale (I. Korps Stab 1966a, 32; 49). Similarly, a fictitious digest of the foreign press that was passed to the players during the exercise praised the German population for its calm response to the threat of nuclear annihilation (I. Korps Stab 1966b).

In the subterranean space of the bunker, the West German elites can therefore be seen to have replayed the state's abandonment of its citizens and the annihilation of 'own' settlements from above. It therefore becomes clear that the bunker, as the very particular locus of this fundamentally unplayful game, served to re-enact traumatic experiences in front of the very nations (now NATO allies) that had unleashed the urbicide of cities like Dresden or Cologne. In a sense, West Germany was enjoying the forbidden fruit of geo- and biopolitics. As members of NATO, the West German elites could at least pretend to have some control over the act of extermination, even though the final decision on the use of nuclear weapons lay with the US President. In the simulated killing of own cities, they had found a stick on a string that gave them an illusion of control. From their place in the bunker, they ironically saw their own towns and villages from the perspective of an Allied bombing squad - as a toy that they could make disappear on a map.

Writing in 1985, the psychoanalyst Carl Nedelmann noted the way in which Anglo-American defence experts knew Germany only as the 'nuclear theatre' during most of the Cold War (Nedelmann 1985, 17). Nedelmann suggested that the Federal Republic's elites knew this very well and were suffering from a sense of inferiority vis-àvis its Allies that was further increased by the failed attempts to acquire own nuclear weapons during the chancellery of Konrad Adenauer (21). Drawing on the psychoanalytic insight that the failure to achieve goals tends to give rise to emotions of inferiority and guilt, he claimed that West Germany's sovereignty deficit functioned as the 'open wound' of Germany's national identity. The feelings of inferiority and guilt that became so characteristic of post-war German nationalism may have therefore been rooted not merely in the genocidal war that Germany had inflicted upon the world but also in its failure to have achieved great power status after the war.

\section{Conclusion}

In this article I have sought to draw attention to the unplayful nature of war games. I have argued that the West German participation in the 1966 nuclear war game Fallex 66 is best understood as a compulsion to repeat. Bonn's willingness to destroy and radioactively contaminate own territory showed not just determination to discourage a Soviet attack but a compulsion to self-harm. Rather than a mere enactment of Cold War deterrence, Bonn's war game was a re-enactment that compulsively repeated the fundamental bio- and geopolitical trauma that gave birth to the young West German state: the annihilation of German cities through Allied bombing campaigns and the restriction of West German sovereignty. In this way, the Bonn Republic abandoned its dwellings in a struggle against 'totalitarian' Communism in much the same way that the Allies had sacrificed those towns and cities in the struggle against fascist totalitarianism two decades earlier.

West Germany's compulsion to repeat has implications for how we understand geopolitical play more generally. Whilst Fallex 66 did indeed display ludic elements, the war game was devoid of the very ingredients that make a game playful, such as spontaneity, disruption and creativity. At the heart of Fallex was not playful experimentation but a self-destructive compulsion to repeat a trauma caused by an experience of loss. If it was a game, then it was only a 'fort da' game in which the semi- 
sovereign West German state transposed the unequal power relations between its new allies and itself onto its relationship with its own civilian population - only this time simulating control of the situation. The game's true aim for West Germany then was to master rather than mourn the experience of urbicide and bunker life.

Ultimately, nuclear play is a very particular type of game because it incorporates within it the point from which the game can no longer be replayed. As Hanna Segal noted, nuclear warfare had made it possible to 'annihilate the world, but not reconstruct it' (Segal, 1995: 197). Whilst, in other words, the two bloc's ever expanding nuclear arsenals made the 'fort' increasingly easy to achieve, the reality of nuclear overkill was rendering the possibility of the 'da' vanishingly small. This 'world of primitive omnipotence', Segal held, was governed not by the fear of death but 'by wishes for annihilation of the self and the world, and the terrors associated with it' (ibid). And yet, nuclear play, to use that euphemism one last time, was maybe not all that different from Ernst's fort-da game. For although the arms race was making a 'replay' highly unlikely, emergency planners were of course fantasising about the world's repopulation after a nuclear war. Indeed, NATO continued to refer the final part of Fallex 66 quite casually to a 'post nuclear setting' (Northern Army Group 1966: C/2). It is this insistence on the possibility of a post-apocalyptic world that shows the limits of the death drive even within the fantasy of nuclear Armageddon. 


\section{Bibliography}

I. Korps Stab 1966a Kriegstagebuch 121120oZ, Military Archives Freiburg, BH 7-1/428

I. Korps Stab 1966b Nachrichten und Kommentare Fallex 66, Military Archives Freiburg 7-1/428

III. Korps Chef des Stabes 1966 Inhalt von PSK Maßnahmen 18190oZ, Military Archives Freiburg, BH 7-3/854

III. Korps Fernschreibestelle 1966 Die Rede des Herrn Bundespräsidenten 201845Z, Military Archives Freiburg, BH 7-3/854

III. Korps Leitung 1966 G3 sofort verlegen !!! 222335Z, Military Archives Freiburg, BH $7-3 / 845$

III. Korps Leitungsstab 1966 FALLEX 66 Exercise Top Gear 180615Z, Military Archives Freiburg, $\mathrm{BH}$ 7-3/854

Adenauer K 1946 16. März 1946: Brief an William F. Sollmann, Pendle Hill, Wallingford/Pennsylvanien available at http://www.konradadenauer.de/dokumente/briefe/brief-sollmann [accessed 5 January 2015]

Adey P \& Anderson B 2012 Anticipating emergencies: Technologies of preparedness and the matter of security Security Dialogue 43 99-117

Afheldt H 1983 Defensive Verteidigung Hamburg, Rowolth

Agamben G 2005 State of exception Chicago, University of Chicago Press

Bald D 2008 Politik der Verantwortung Berlin, Aufbau Verlagsgruppe

Bassin M 2003 Between the realism and the "New Right": Geopolitics in Germany in the 1990 Transactions of the Institute of British Geographers 28 350-366

Beck J 2011 Concrete ambivalence Inside the bunker complex Cultural Politics 71 79-102

Bennett L 2011a Bunkerology - a case study in the theory and practice of urban exporation Environment and Planning D 29 421-434

Bennett L 2011b The Bunker Metaphor, materiality and management Culture and Organization 17 155-173

Berliner Zeitung 1966 "Panzerfaust” gegen “revoltierenden Mob” 18 November 1966

Berliner Zeitung 1975 Überfall im Regierungsbunker: Minister Lebers Sekretärin niedergestochen 19 March 1975

Borch-Jacobsen M 1982 The Freudian subject Houndsmills, Macmillan

Borinski P 1989 Mitigating West Germanys strategic dilemmas Armed Forces E Society 15 531-549

Bundesinnenminsterium 1959 Gutachten zur Bestandsaufnahme für Alagen des THW, Dr.-Ing. P. Walter 15 April 1959 Federal Archives Koblenz B157/6094

Bundesinnenministerium 1960 An den Herrn Bundesminister für Verkehr z.Hd. Herrn MinRat Busse o.V.i.A. March 196o Federal Archives Koblenz B106/5041

Buteux P 1983 The politics of nuclear deterrence in NATO 1965-1980 Cambridge, Cambridge University Press

Carter S Kirby P \& Woodyer T 2015 'Ludic - or playful - geopolitics' in Benwell M, \& Hopkins $\mathbf{P}$ eds Children, young people and critical geopolitics Farnham, Ashgate 
Cioc M 1988 Pax atomica: The nuclear defense debate in West Germany during the Adenauer era (New York: Columbia University Press)

Ciută F 2015 Call of duty: Playing video games with IR Millennium: Journal of International Studies doi: 10.1177/0305829815601488

Dalby S 1990 American security discourse and the persistence of geopolitics Political Geography Quarterly 9 171-188

Davis T C 2007 Stages of emergency: Cold War nuclear civil defence Durham and London, Duke University Press

Der Spiegel 1957 Die Bombe im Schiff 15 May 1957

Der Spiegel 1962 Bedingt abwehrbereit 10 October 1962

Der Spiegel 1966a Tischtuch für Generale 24 October 1966

Der Spiegel 1966b Bier im Berg 17 October 1966

Der Spiegel 1985 Auf breiter Front 24 June 1985

Der Derian J 2001 Virtuous war: Mapping the military-industrial-media-entertainment network Boulder, Westview

Die Zeit 1966a Regierung unter Tage 21 October 1966437

Die Zeit 1966b Der Aufstand der Linken 2 December 1968498

Diester J 2009 Geheimakte Regierungsbunker: Tagebuch eines Staatsgeheimnisses Düsseldorf, Verlagsanstalt Handwerk GmbH

Diester J and Karle M 2013 Plan B Bonn, Berlin und ihre Regierungsbunker Düsseldorf, Verlagsanstalt Handwerk GmbH

Dittmer J 2013 Humour at the United Nations: the role of laughter in constituting geopolitical assemblages Geopolitics 18 493-513

Dorn W 2002 So heiss war der kalte Krieg: Fallex 66 Berlin Dittrich Verlag

Ebeling W 1986 Schlachtfeld Deutschland? Friedberg, Podzun-Pallas-Verlag

Freitag J \& Hensel H 2010 Honeckers geheimer Bunker 5001 Stuttgart, Motorbuchverlag

Freud S 2001 [1913] Totem and taboo London, Routledge

Freud S 2001 [1920] Beyond the pleasure principle, group psychology and other works London, Vintage

Freud S 1989 [1930] Civilization and its discontents London, Norton

Geenen E 2006 Der kalkulierte Tod, in Bundesbauamt für Bauwesen und Raumordnung ed Der Regierungsbunker Berlin und Tübingen, Ernst Wasmuth Verlag 42-51

Graham S 2006 Cities and the "War on Terror" Journal of Urban and Regional Research $30255-276$

Gregory D 2011 "Doors into nowhere" Dead cities and the natural history of destruction, in Meusburger P, Heffernan M \& Wunder E eds Cultural memories: The Geographical point of view Heidelberg, London and New York, Springer 249-283

Hughes R 2010 Gameworld geopolitics and the genre of the quest, in MacDonald F Hughes R and Dodds K eds Observant states: Geopolitics and visual culture London, I B Tauris 123-142 
Jacobsen K 2013 Why Freud matters: Psychoanalysis and International Relations Revisited International Relations 27 393-416

Jungbluth U 2000 Wunderwaffen im KZ "Rebstock" Briedel, Rhein-Mosel Verlag

Kingsbury P 2008 Did somebody say jouissance? On Slavoj Žižek, consumption, and nationalism Emotion, Space and Society 1 48-55

Kingsbury P 2010 Locating the Melody of the Drives The Professional Geographer, 624 519-533

Kingsbury P \& Pile S 2014 The unconscious, transference, drives and other things tied to geography, in Kingsbury P \& Pile S eds Psychoanalytic Geographies Farnham, Ashgate

Lenoir $\mathbf{T} 2000$ All but war is simulation: The military entertainment complex Configurations 8 238-335

MacDonald F 2008 Space and the atom: On the popular geopolitics of Cold War rocketry Geopolitics 13 611-634

Mastny V \& Byrne M 2006 A cardboard castle? An inside history of the Warsaw Pact Budapest \& New York, CEU Press

Ministerium für Nationale Verteidigung 1964 Kurzfassung "Bericht über die Kampfbereitschaft, den Ausbildungsstand, und die Dislozierung der Kernwaffeneinheiten der NATO-Land- und Luftstreitkräfte in Westdeutschland 15 June 1964 Military Archives Freiburg DVW 1/25784/e

Ministerium für Staatssicherheit 1966a Sonderbericht Nr. 2/66 der Verwaltung Aufklärung des MfNV, 1 November 1966, The Federal Commissioner for the Stasi Archives, MfS ZAIG Nr. 6630

Ministerium für Staatssicherheit 1966b Einzel-informationen über Erfahrungsbericht des Bundesverteidigungsministeriums über die NATO Übung "Fallex 66", 1 July 1966, The Federal Commissioner for the Stasi Archives, MfS Hauptverwaltung Aufklärung Nr. 225

Ministerium für Staatssicherheit 1966c Fallex 66 - oder Aggressionskrieg heute, no date, The Federal Commissioner for the Stasi Archives, MfS HA IX/MF/11992

Ministerium für Staatssicherheit 1966d Notstandsregelungen bei "Fallex 66", 7 November 1966, The Federal Commissioner for the Stasi Archives, MfS ZAIG/1 9040

Ministerium für Staatsicherheit 1967 Dokumentation über de Ausweichführungspunkte der Bonner Regierung, des Bundesinnenministeriums und des Bundesverteidigungsministerium in der Eifel, 23 February 1967, The Federal Commissioner for the Stasi Archives, MfS o6o Nr.75/67

Müller M 2013 Lack and jouissance in hegemonic discourse of identification with the state Organization 20 279-298

Nast H 2003 Oedipalizing geopolitics: A commentary on Condensing the Cold War Geopolitics 8 190-196

Nedelmann C 1985 Von der deutschen Minderwertigkeit Nedelmann C ed Zur Psychoanalyse der nuklearen Drohung Göttingen, Verlag für medizinische Psychologie: 11-34

Neues Deutschland 1966a ...und Lücke befahl den Notstand 23 October 1966 
Neues Deutschland 1966b Fallex 66 Westdeutsche Städte im Kernwaffenhagel, no date, The Federal Commissioner for the Stasi Archives, MfS ZAIG 9040

No author 1966 Tatort Ahrweiler The Federal Commissioner for the Stasi Archives, MfS ZAIG 11114

Northern Army Group 1966 COMNORTHAGS post-exercise report, 7 December 1966, Military Archives Freiburg 7-1/27

Ó Tuathail G \& Agnew J 1992 Geopolitics and discourse: Practical geopolitical reasoning in American foreign policy Political Geography 11 190-204

Pile S 1996 The body and the city Psychoanalysis, Space and Subjectivity London \& New York, Routledge

Pile S 2001 The unknown city...or, an urban geography of what lies buried below the surface Borden I et al. eds The unknown city contesting architecture and urban space Cambridge, MIT Press 262-279

Power M 2007 Digitized virtuosity: Video war games and post-9/11 cyberdeterrence Security Dialogue 38 271-88

Salter M B 2011a Gaming world politics: Meaning of play and world structure International Political Sociology 54 453-456

Salter M B 2011b The Geographical Imaginations of Video Games Diplomacy, Civilization, Americas Army and Grand Theft Auto IV Geopolitics, 16 359-388

Sebald W G 1999 On the natural history of destruction London Hamish, Hamilton

Segal H 1995 From Hiroshima to the Gulf War and after: a psychoanalytic perspective Elliot A \& Frosh S eds Psychoanalysis in contexts: Paths between theory and modern culture London, Routldge 191-204

Segal H 1997 Psychoanalysis, literature and war: Papers 1972-1995 London, Routledge

Shaw I G R 2010 Playing war Social E Cultural Geography 11 789-803

Shaw I G R, Powell J \& De La Ossa J 2014 Towards a psychoanalytic geopolitics the militarization of public schooling in the USA Kingsbury $\mathbf{P} \&$ Pile $\mathbf{S}$ eds Psychoanalytic Geographies Farnham, Ashgate

Shaw I G R \& Sharp J 2013 Playing with the future: Social irrealism and the politics of aesthetics Social \& Cultural Geography 14 341-359

Social \& Cultural Geography 2003 Special Issue on psychoanalytic geographies 43 283399

Stahl R 2010 Militainment, Inc.: War, media, and popular culture London, Routledge

Süddeutsche Zeitung 1985 Im Bunker den Papier-Krieg überstehen 20 February 1985

Thoß B 2007 Der Regierungsbunker in der Strategie der atomaren Abschreckung Bundesamt für Bauwesen und Raumordnung ed Der Regierungsbunker Berlin und Tübingen Ernst Wasmuth Verlag

Tribüne 1967 Süsses Leben im Notstandsbunker 1o March 1967

UK Ministry of Defence 1967 Fallex 66 - Post exercise report, 20 January 1967, The National Archives, Kew CAB 164/77

Vanderbilt T 2002 Survival city: Adventures among the ruins of atomic America New York, Princeton Architectural Press 
Virilio P 1975 Bunker archaeology New York, Princeton Architectural Press

Volksblatt Berlin 1985 'NATO “spielt” dritter Weltkrieg' 1 March 1985

von Hilgers P 2012 War games: A history of war on paper Cambridge and London, MIT Press

Welt im Bild 1953 Welt im Bild: Die Allianz Wochenschau 70/53 28 October 1953

Woodyer T 2012 Ludic geographies: Not merely child's play Geography Compass 66 313326

Yarwood R 2015 Miniaturisation and the representation of military geographies in recreational wargaming Social \& Cultural Geography, DOI: $10.1080 / 14649365.2014 .1001430$

Zehfuss M 2007 Wounds of memory: The politics of war in Germany Cambridge, Cambridge University Press

Žižek S 1991 Looking awry: an introduction to Jacques Lacan through popular culture, Cambridge, MIT Press 